\title{
Production of Iron from Mill Scale Industrial Waste via Hydrogen
}

\author{
N. M. Gaballah ${ }^{1}$, A. F. Zikry ${ }^{1}$, M. G. Khalifa ${ }^{2}$, A. B. Farag $^{1}$, N. A. El-Hussiny ${ }^{3}$, M. E. H. Shalabi ${ }^{3^{*}}$ \\ ${ }^{1}$ Faculty of Science, Helwan University, Cairo, Egypt \\ ${ }^{2}$ El-Tabbin Metallurgical Institute, Cairo, Egypt \\ ${ }^{3}$ Central Metallurgical Research and Development Institute, Cairo, Egypt \\ Email: *shalabimeh@hotmail.com.mail
}

Received November 16, 2012; revised December 15, 2012; accepted December 30, 2012

Copyright (C) 2013 N. M. Gaballah et al. This is an open access article distributed under the Creative Commons Attribution License, which permits unrestricted use, distribution, and reproduction in any medium, provided the original work is properly cited.

\begin{abstract}
Mill scale is very attractive industrial waste due to its richness in iron (about $=72 \% \mathrm{Fe}$ ). In this paper, the characterizations of mill scale were studied by different methods of analyses. The produced mill scale briquettes were reduced with hy- drogen at varying temperatures, and the reduction kinetics was determined. Two models were applied and the energy of activation was calculated.
\end{abstract}

Keywords: Mill Scale; Reduction by Hydrogen; Energy of Activation

\section{Introduction}

In several iron and steel making processes, about 500 $\mathrm{kg} / \mathrm{ton}$ of solid wastes of different nature are generated; one of these wastes is the mill scale which represents about $2 \%$ of steel produced [1]. Mill scale is a very attractive industrial waste due to its richness in iron [about = $72 \% \mathrm{Fe})[2]$.

In the whole world, 13.5 million tons of mill scales are generated annually [3]. Mill scale is suitable for direct recycling to the blast furnace via sintering plant [4]. Approximately, $90 \%$ of mill scale is directly recycled within steelmaking industry and small amounts are used for ferroalloys, in cement plants and in the petrochemicals industry [5-8].

El-Hussiny et al. [9] studied the replacement of some amount of Baharia high barite iron ore concentrate by mill scale waste and they indicated that, replacement of some iron ore by mill scale increased the amount of readymade sinter, sinter strength and productivity of the sintering machine and productivity of blast furnace yard.

The reduction of iron oxides via gaseous and solid reductants has already been extensively studied [1].

Maurício et al., studied the kinetics of scale reduction by carbon monoxide in the temperature ranging in $800^{\circ} \mathrm{C}$ $1200^{\circ} \mathrm{C}$ and the results indicated that un-reacted shrinking core model with one interface under chemical reaction control fits well with the experimental data at the initial

\footnotetext{
${ }^{*}$ Corresponding author.
}

stage of reduction and the activation energy about 80 $\mathrm{kJ} / \mathrm{mol}[1]$.

Benchiheub et al. [2] found that the best reduction of mill scale was obtained at $1050^{\circ} \mathrm{C}$ at $180 \mathrm{~min}$ in pure carbon monoxide gas.

It was indicated that with increase in the temperature, the percentage reduction increases with increase in time and the activation energy of reduction depends upon the type of binder [10].

Kawasaki et al. [11] found that varying total pressure of the reduction system by hydrogen and carbon monoxide had no effect on the rate of reduction. Commercial iron powders are classified in three types, reduced iron powder, atomized iron powder, and electrolytic iron powder, depending on the production method and are used in various applications, taking advantage of their respective properties.

Iron powders are used in many different industries for many different applications. Followings are some examples of the iron powder uses: Brazing, Sintered Products, Friction Products, Soft Magnetic Products, Chemicals, Metallurgy, Filtration, Printing, Surface Coating, Welding, Iron Fortification.

Iron powder cores are commonly used to produce high $\mathrm{Q}$ inductors and transformers for selective circuits. Iron powder cores used in RF applications are composed of extremely small particles of highly pure carbonyl iron.

This study aims at investigating the reduction kinetic of 
Egyptian mill scale briquette via hydrogen to produce iron powder.

\section{Experimental Work}

\subsection{Material}

The rolling mill scale used in this work was provided by mill of Egyptian iron and steel Co. The sample was submitted to chemical and X-ray analysis was done by Brucker AXS_D8Advnce.

The chemical analyses of mill scale are illustrated in Table 1.

Ray analysis is illustrated in Figure1. From which it is clear that mill scale mainly consists of magnetite, wustite, iron, quartz and hematite.

\subsection{Preparation of the Briquetting and Its Physical Properties}

The mill scale was grinding in vibrating mill to powder with size less than 75 micrometers. The mill scale powder $(10 \mathrm{~g})$ are mixed with $2 \%$ molasses and then pressed under different pressure (the pressure range from $75 \mathrm{MPa}$ up to $275 \mathrm{MPa}$ ). The briquette subjected to drop number test and crushing strength tests. The drop number indicates how often green briquette can be dropped from a height 46 $\mathrm{cm}$ before they show perceptible cracks or crumble. Ten green briquettes are individually dropped on to a steel plate. The number of drops is determined for each briquette. The arithmetical average values of the crumbing behavior of the ten briquettes yield the drop number.

Table 1. The chemical analyses of mill scale.

\begin{tabular}{cc}
\hline Element & Weight $\%$ \\
\hline $\mathrm{Fe}$ (total) & 69.33 \\
$\mathrm{Fe}^{+2}$ & 49 \\
$\mathrm{Fe}^{+3}$ & 12.5 \\
$\mathrm{FeO}$ & 7.83 \\
$\mathrm{~S}$ & 0.33 \\
$\mathrm{P}$ & 0.22 \\
$\mathrm{Mn}$ & 0.51 \\
$\mathrm{Si}$ & 0.9 \\
\hline
\end{tabular}

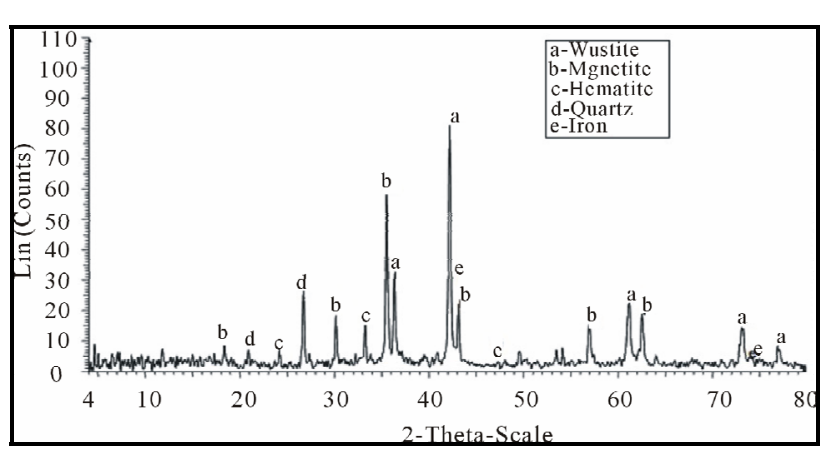

Figure 1. X-Ray analysis of mill scale sample.
The average crushing strength is done by compressed 10 briquettes between parallel steel plates up to their breaking [12].

\subsection{Reduction Process}

The reduction of mill scale by hydrogen was done in a thermo balance apparatus. (A schematic diagram of thermo balance apparatus is shown in Figure 2 [13]. It consisted of a vertical furnace, electronic balance for monitoring the weight change of reacting sample and temperature controller. The sample was placed in a nickel chrome crucible which was suspended under the electronic balance by $\mathrm{Ni}-\mathrm{Cr}$ wire. The furnace temperature was raised to the required temperature $\left(650^{\circ} \mathrm{C}-950^{\circ} \mathrm{C}\right)$ and maintained constant to $\pm 5^{\circ} \mathrm{C}$. Then samples were placed in hot zone.

The nitrogen flow rate was $0.5 \mathrm{l} / \mathrm{min}$ in all the experiments. At initial time air should be removed before each experiment and also after the end of reduction. The weight of the sample was continuously recorded at the end of the run; the samples were withdrawn from the furnace and put in the desiccators.

The percentage of reduction was calculated according to the following equations:

$$
\text { Percent of reduction }=\frac{\left(\mathrm{W}_{0}-\mathrm{W}_{\mathrm{t}}\right) * 100}{\text { Oxygen }(\text { mass })}
$$

where:

$\mathrm{W}_{0}$ : the initial mass of mill scale sample after removal of moisture.

$\mathrm{W}_{\mathrm{t}}$ : mass of sample after each time, $\mathrm{t}$.

Oxygen (mass): indicates the mass of oxygen percent in mill scale in form $\mathrm{FeO}$ and $\mathrm{Fe}_{2} \mathrm{O}_{3}$.

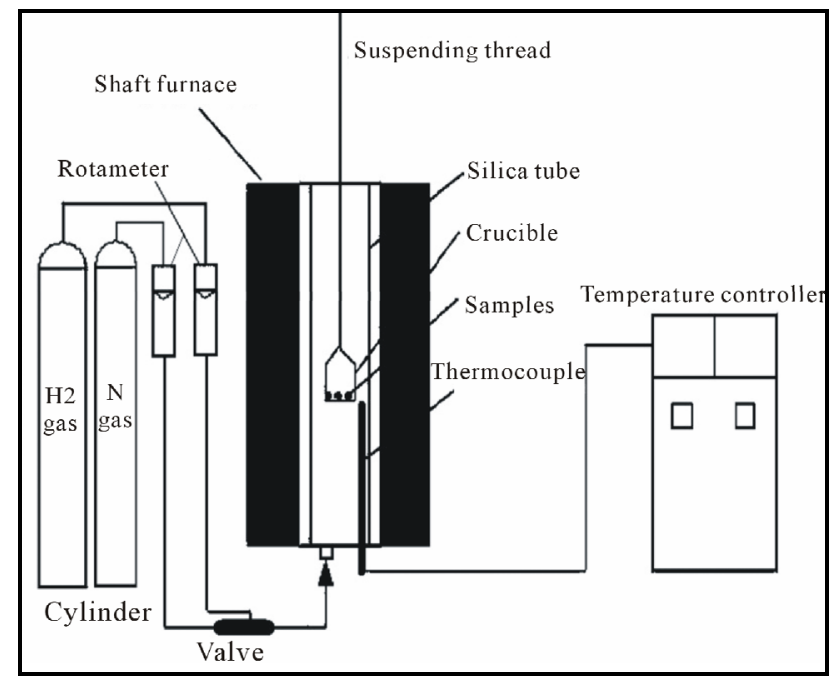

Figure 2. A schematic diagram of thermo balance apparatus (13). 


\section{Results and Discussion}

\subsection{Effect of the Pressure Load with Constant Amount of Binding Material on the Quality of the Briquette}

Figures 3 and 4 show the relation between the change of pressure load at constant amount of molasses $(2 \%)$ on the drop number (drop damage resistance) and cold crushing strength of the briquette It is clear that as the pressing pressure load increased both the drop damage resistance and crushing strength increased. This may be due to the fact that increase pressure load increases the compaction of briquette and subsequently the Vander Waals forces increased [14,15], also the increase of briquetting pressure leads to progressive crushing of the macro pores [16].

\subsection{Effect of Flow Rate on the Degree of Reduction}

Figure 5 illustrated the effect of change hydrogen flow rate on the degree of reduction of mill scale briquette at $900^{\circ} \mathrm{C}$ (pressure load 216.85 MPa). From this figure it is clear that the degree of reduction increased as the hydrogen flow rate increased. This may be attributed that the increase of flow rate leads to an increase of number of hydrogen mole in the bulk phase, which in turn leads to the raise of hydrogen adsorption and subsequently the rate of reaction increased [17] or the increase of flow rate increased the gas diffusion across the boundary layer

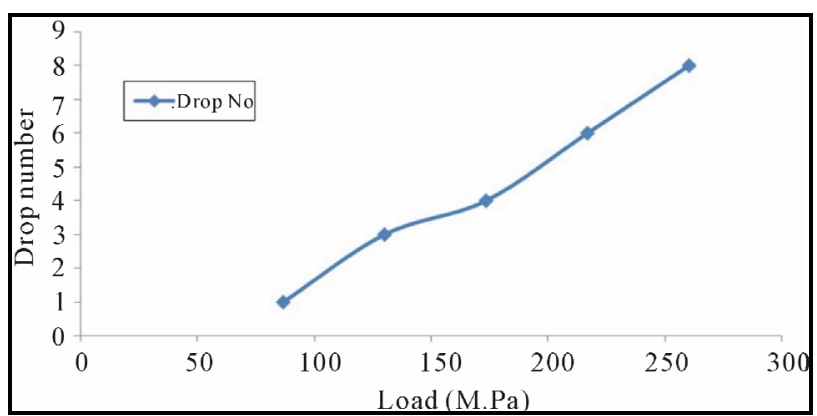

Figure 3. Relationship between the change of pressure load and drop no. of mill scale briquette.

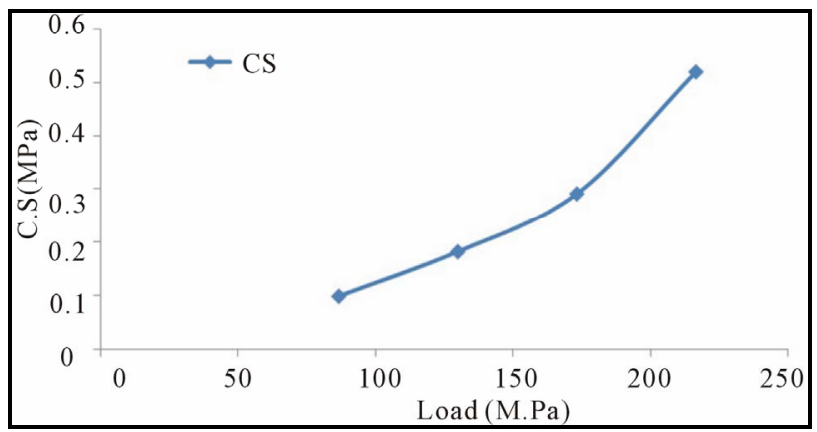

Figure 4. Relationship between the change of pressure load and cold crushing strength (C.S) of mill scale briquette.

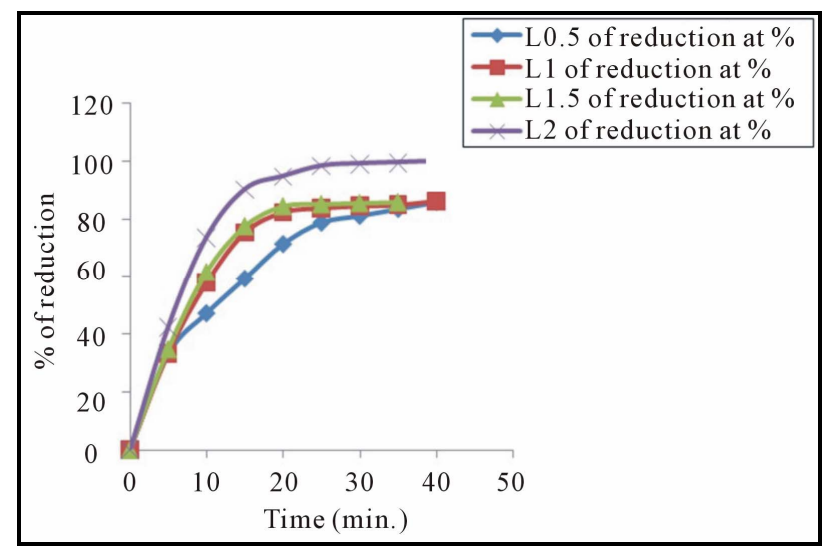

Figure 5. Effect of change hydrogen flow rate on the degree of reduction of mill scale briquette. (Pressure load 216.85 $\mathrm{MPa}$, and temperature of reduction $900^{\circ} \mathrm{C}$ ).

subsequently the reduction ion increased [18]. Also may be the higher flow rate prevailing in the reaction zone which enhances the rate of hydrogen absorption and subsequently the rate of chemical reaction steps increased [19].

\subsection{Effect of Temperature on the Reduction Degree of Mill Scale Briquettes}

Experiments were performed for briquette which pressed at load $216.85 \mathrm{MPa}$, in the temperature range of $650^{\circ} \mathrm{C}$ to $950^{\circ} \mathrm{C}$ in hydrogen atmosphere $(2 \mathrm{~L} / \mathrm{min})$. Plots of the reduction percentage as a function of time are shown in Figure 6. From this figure, it is clear that the reduction rates increased with increasing temperature. At high reduction temperatures (more than $900^{\circ} \mathrm{C}$ and up to $950^{\circ} \mathrm{C}$ ), with increasing temperature, the oxygen removal favorable increased.

The analyses of the curves relating the reduction percentage and time of reduction, shows that each curve has 3 different slopes indicating 3 different values of reduction rates. The first value is high, while the second is somewhat slower and the third is slowest one. The increase of reduction percentage with rise of temperature may be due to the increase of number of reacting moles having excess of energy which leads to the increase of reduction rate $[17,20]$. Also the raise of temperature leads to an increase of the rate of mass transfer of the diffusion and rate of desorption [18-21].

\subsection{Kinetics Reduction of Mill Scale Briquette}

Using two models:

1) Diffusion process controls equation Ginsling-Brounshtein $[22,23]$.

$$
1-(2 / 3) \mathrm{R}(1-\mathrm{R})^{2 / 3}=\mathrm{kt}
$$




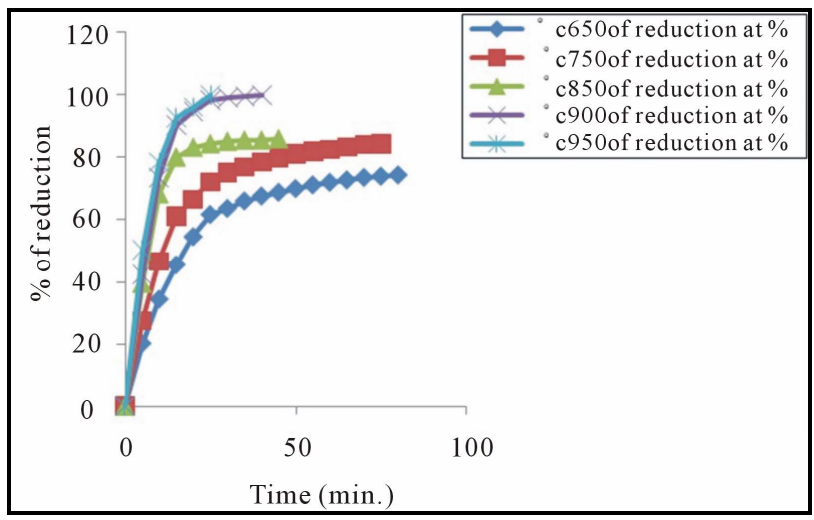

Figure 6. Effect of change temperature on the reduction degree of mill scale briquettes.

2) Diffusion process controls equation [24].

$$
1-(1-\mathrm{R})^{0.5}=\mathrm{kt}
$$

Where $\mathrm{R}$ is fractional reduction, $\mathrm{t}$ is time of reduction, $\mathrm{k}$ is the rate constant.

Figure7, illustrates the relation between $1-(2 / 3) \mathrm{R}-(1$ - R) 2/3 against time of reduction for different reduction temperatures. From which it is clear that the straight line was observed.

The natural logarithms were used according to the Arrhenius equation to calculate the activation energies of reduction reaction. The results illustrate in Figure 8. From which it is clear that the activation energy $=72.25 \mathrm{~kJ}$ /mole.

Figure 9 illustrate the relation between $1-(1-\mathrm{R})^{0.5}$ against time of reduction for different reduction temperature. From which it is clear that the nearly straight line was observed.

The natural logarithms were used according to the Arrhenius equation to calculate the activation energies of reduction reaction. The results illustrate in Figure 10 from which it is clear that the activation energy $=61.5$ $\mathrm{kJ} /$ mole.

\section{X-Ray Analysis of Some Reduced Samples}

Figures 11 and 12 illustrate $x$-ray analyses of a reduced mill scale at different temperatures $\left(650^{\circ} \mathrm{C}-950^{\circ} \mathrm{C}\right)$ in hydrogen atmosphere. From which it is clear that the reduction at high temperature more iron is produced and reached to about $100 \%$.

\section{Microscopic Analyses}

Figures 13 and 14 show that the microscopic analyses of the produced mill scale briquette in hydrogen atmosphere at temperatures $650^{\circ} \mathrm{C}$ and $950^{\circ} \mathrm{C}$. From which it is clear that the microscopic analyses of the reduced briquette at $650^{\circ} \mathrm{C}$ are wustite, iron and pore, while the microscopic analyses of reduced briquette at $950^{\circ} \mathrm{C}$ is iron

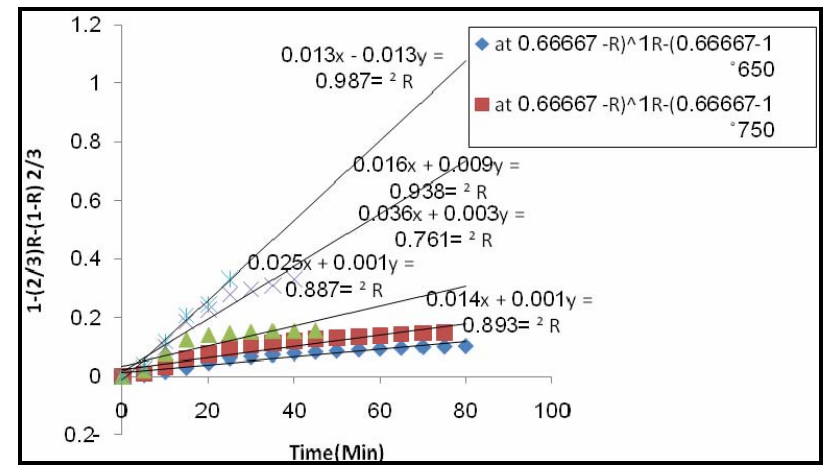

Figure 7. The relationship between time of reduction and 1 $(2 / 3) R-(1-R) 2 / 3$ at different temperatures.

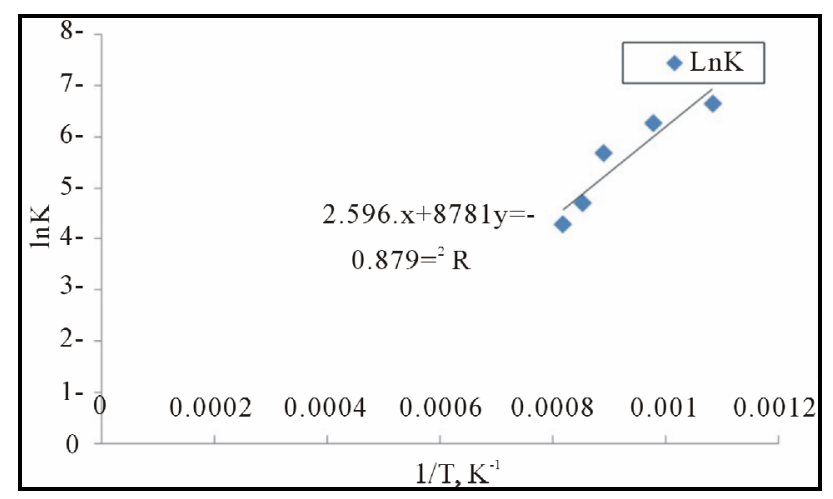

Figure 8. The relation between $1 / T$ and $\ln K$ for first model (Arrhenius plot for reduction reaction.

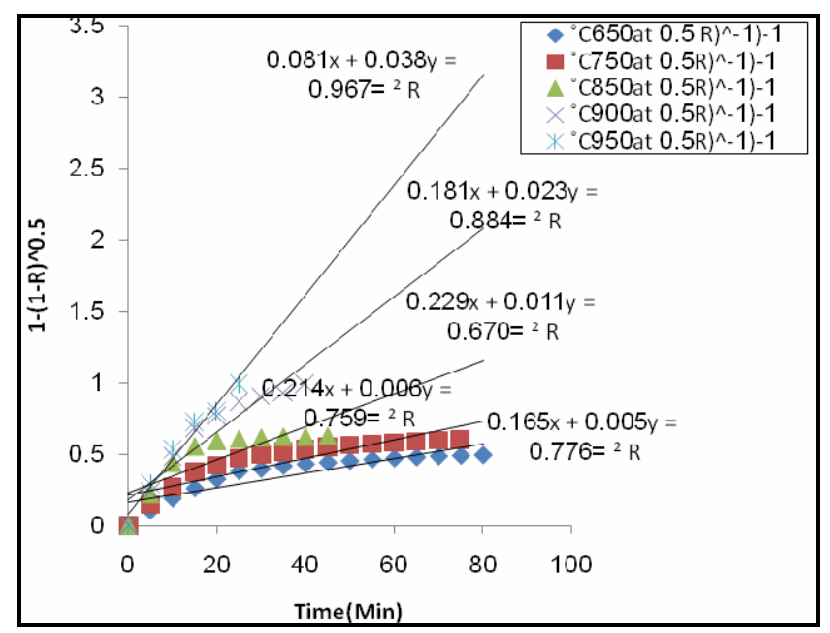

Figure 9. The relationship between time of reduction and 1$(1-R) 0.5$ at different temperature.

and pore.

\section{Conclusions}

Mill scale is very attractive industrial waste due to its richness in iron (about $=72 \% \mathrm{Fe}$ ).

The pressing pressure loading in the briquetting process of mill scale powder increased both the drop damage 


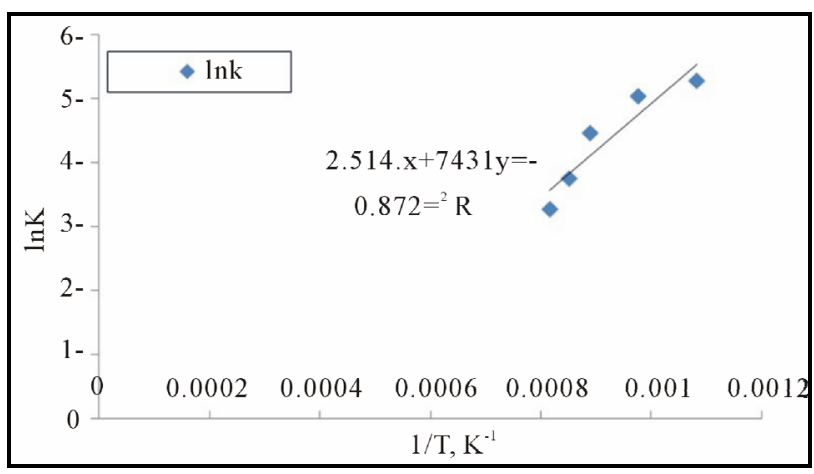

Figure 10. The relation between $1 / T$ and $L n K$ for second model (Arrhenius plot for reduction reaction.

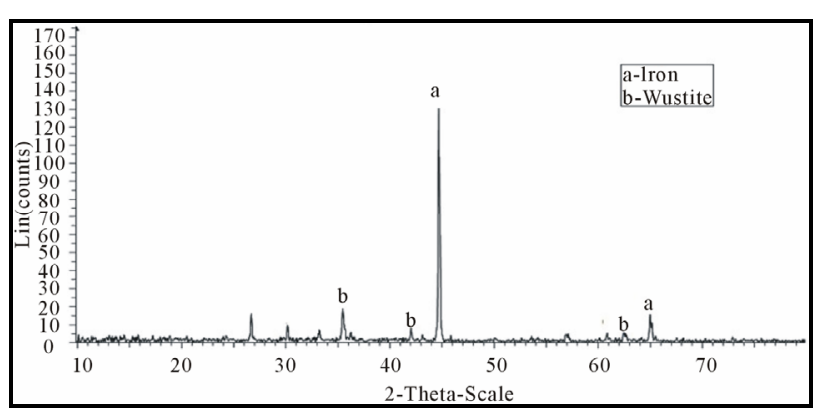

Figure 11. X-ray analysis of sample produced at $650^{\circ} \mathrm{C}$.

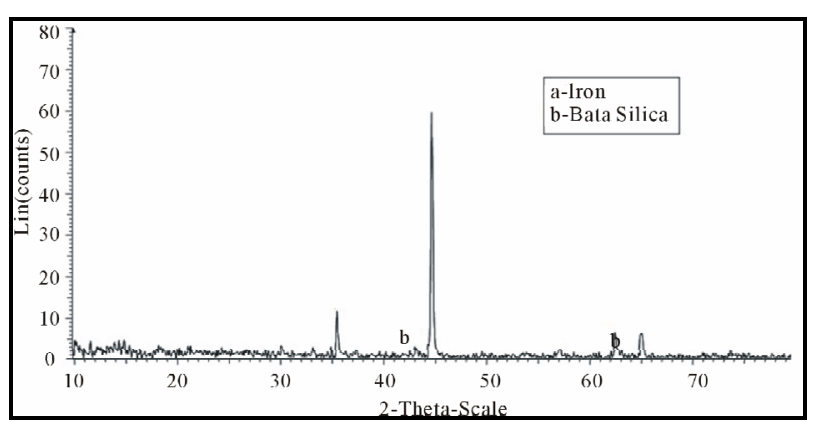

Figure 12. X-ray analysis of sample produced at $950^{\circ} \mathrm{C}$.

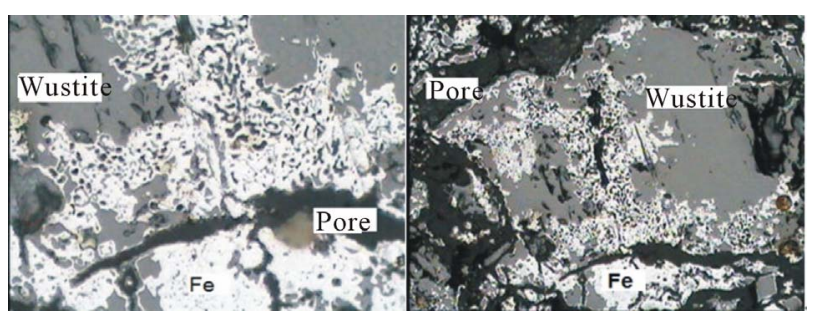

(a)

(b)

Figure13. Microscopic structure of the reduced mill scale briquette at $650^{\circ} \mathrm{C}$. (a) $X=\mathbf{2 0 0}$; (b) $X=500$.

resistance and crushing strength increased.

The degree of reduction of mill scale briquettes at constant temperature increased as the hydrogen flow rate increased.

The reduction rate of mill scale briquettes under a cons-

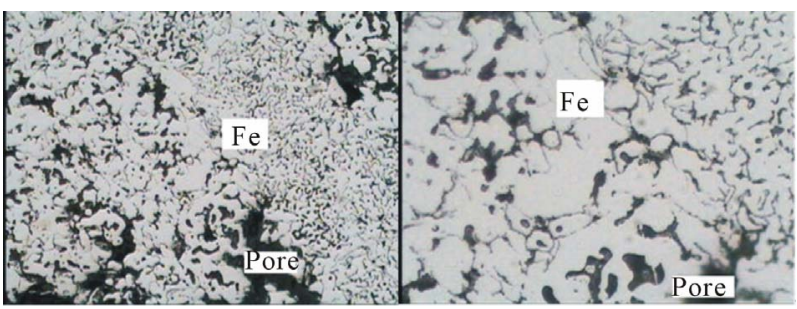

(a)

(b)

Figure 14. Microscopic structure of the reduced mill scale briquette at $950^{\circ} \mathrm{C}$. (a) $X=200$; (b) $X=500$.

tant flow rate of hydrogen (as reducing agent) with increasing temperature.

The kinetic reduction of mill scale briquettes shows that the reduction process is controlled by diffusion process and the energy of activation is ranged between (61.5 $72.25 \mathrm{KJ} / \mathrm{mol})$.

\section{REFERENCES}

[1] M. C. Bagatini, V. Zymla, E. Osório and A. C. F. Vilela, "Characterization and Reduction Behavior of Mill Scale," Isij International, Vol. 51, No. 7, 2011, pp. 1072-1079.

[2] O. Benchiheub, S. Mechachti, S. Serrai and M. G. Khalifa, "Elaboration of Iron Powder from Mill Scale," Journal of Materials and Environmental Science, Vol. 1, No. 4, 2010, pp. 267-276.

[3] S. Cho and J. Lee, "Metal Recovery from Stainless Steel Mill Scale by Microwave Heating," Metals and Materials International, Vol. 14, No. 2, 2008, pp. 193-196, 20054149.

[4] A. M. Fleischanderl, "Managing Steel Wastes and ByProducts: Crisis and Opportunity," Gorham/Intertech's 13th International Iron and Steel Development Forum, Antwerp, 11-14 May 1998, pp. 45-50.

[5] Y.-K. Cho, "Making Method for Ferrite Used Mill Scales," Patent Kr 9103783, June 1991.

[6] D. Osing, "Reuse of Metallurgical Fines," Patent Wo 96/ 31630, 1996.

[7] A. Fleischanderl, J. Pesl and W. Gerbert, "Aspect of Recycling of Steelworks By-Products through the Bof," Seaisi Quarterly, Vol. 28, No. 2, 1999, pp. 51-60.

[8] A. Poulalion, "Process of Recycling Mill Scale of Alloyed Steel in an Electric Furnace into a Ferro-Silicon Product," Patent Ep 1122319, 2001.

[9] N. A. El-Hussiny, F. M. Mohamed and M. E. H. Shalabi, "Recycling of Mill Scale in Sintering Process," Since of Sintering, Vol. 43, No. 1, 2011, pp. 21-31.

[10] S. Keshaarysingh and T. Krishnan, "Reduction Kinetics of Iron Ore Pellets and the Effect of Binders," Thesis of Bachelor of Technology in Metallurgical and Materials Engineering, Department of Metallurgical and Materials Engineering National Institute of Technology Rourkela, 2008.

[11] E. Kawasaki, J. Sanscrainte and T. J. Walsh, "Kinetics of Reduction of Iron Oxide with Carbon Monoxide and Hy- 
drogen," AIChE Journal, Vol. 8, No. 1, 1962, pp. 48-52. doi:10.1002/aic.690080114

[12] K. Mayer, "Pelletization Of Iron Ores," Springer-Verlag Berlin Heidelberg, Berlin, Heidelberg 1980.

[13] N. A. El-Hussiny and M. E. H. Shalabi, "A Self-Reduced Intermediate Product from Iron and Steel Plant Waste Material Using a Briquetting Process," Powder Technology, Vol. 205, No. 1-3, 2011, pp. 217-223. doi:10.1016/j.powtec.2010.09.017

[14] S. J. Mangena and V. M. Du Cann, "Binderless Briquetting of Some Selected South African Prim Coking, Blend Coking and Weathered Bituminous Coals and the Effect of Coal Properties on Binderless Briquetting," International Journal Of Coal Geology, Vol. 71, No. 2, 2007 , 303-312.

[15] F. M. Mohamed, Y. M. Z. Ahmed and M. E. H. Shalabi, "Briquetting of Waste Manganese Ore Sinter Fine Using Different Binding Materials," Environmental Issues and Waste Management in Energy and Mineral Production Swemp, 2004, pp. 567-573.

[16] O. G. Ingles, "Microstructure in Binderless Briquetting, Agglomeration," Interscience Publishers, New York, 1962, pp. 29-53.

[17] M. E. Shalabi, "The kinetics of reduction of Baharia iron ores with hydrogen on static bed," M.Sc., El-Tabbin Metallurgical Institute for Higher Studies, 1973.

[18] S. A. Sayed, G. M. Khalifa, E. S. R. El-Faramawy and M. E. H. Shalabi, "Kinetic Reduction of Low Manganes Iron Ore by Hydrogen," Egyptian Journal of Chemistry, Vol.
45, No. 1, 2002, pp.47-66.

[19] S. A. Sayed, M. G. Khalifa, E. S. R. El-Faramawy and M. E. H. Shalabi, "Reductions Kinetic of El-Baharia Iron Ore in a Static Bed," Gospodarka Surowcami Mineranymi, Vol. 17, Special Issue, 2001, pp. 241-245.

[20] M. E. H. Shalabi, O. A. Mohamed, N. A. Abdel-Khalek and N. A. El-Hussiny, "The Influence of Reduced Sponge Iron Addition on the Quality of Produced Iron Ore Sinter," Proceeding of the XXIMPC, Aachen, 21-26 September 1997, pp. 362-376.

[21] N. A. El-Hussiny, N. A. Abdel-Khalek, M. B. Morsi, O. A. Mohamed, M. E. H. Shalabi and A. M. Baeka, "Influence of Water Amount Added on the Sintering Process of Egyptian Iron Ore," Gornictwo, Vol. 231, 1996, pp. 93115.

[22] Y. M. Wang and Z. F. Yuan, "Reductive Kinetics of the Reaction between a Natural Ilmenite and Carbon," International Journal of Mineral Processing, Vol. 81, No. 3, 2006, pp. 133-140. doi:10.1016/i.minpro.2006.07.010

[23] L. L. C. Amci, S. U. Aydin and C. U. Arslan, "Reduction of Iron Oxides in Solid Wastes Generated by Steelworks," Turkish Journal of Engineering and Environmental Sciences, Vol. 26, No. 1, 2002, pp. 37-44.

[24] A. I. Sabry, A. N. Mahdy and M. F. Abadir, "Thermal Decomposition of $\mathrm{MnCO}_{3}$ in Air," Thermochimica Acta, Vol. 98, No. 1, 1986, pp. 269-276. doi:10.1016/0040-6031(86)87097-6 